logos_i_ethos_2021_(57), s. 107-137

DOI: http://dx.doi.org/10.15633/lie.4034

ks. Miłosz Hołda

https://orcid.org/0000-0003-0649-2168

Uniwersytet Papieski Jana Pawła II w Krakowie

\title{
Tischnera z Kołakowskim spór o łaskę i wolność
}

\section{Wprowadzenie}

Dotyczący problemu relacji między łaską i wolnością spór św. Augustyna z Pelagiuszem nie jest jedynie ciekawym elementem historii ludzkiej myśli. Zapoczątkowany przed wiekami spór odżywał po wielekroć, co więcej - wciąż trwa i można wskazać nowe jego odsłony. Jedną z nich jest ta, o której traktuje poniższy tekst, a mianowicie spór Józefa Tischnera z Leszkiem Koła- ks. Miłosz Hołda, dr hab. filozofii, adiunkt w Katedrze Metafizyki i Filozofii Człowieka na Wydziale Filozoficznym Uniwersytetu Papieskiego Jana Pawła II w Krakowie i wykładowca Katolickiego Uniwersytetu Lubelskiego Jana Pawła II. Jest autorem trzech książek i kilkudziesięciu artykułów naukowych, laureatem Nagrody Prezesa Rady Ministrów za wyróżnioną rozprawę doktorską za rok 2013. Ostatnio opublikował między innymi Źródło i noc. Wprowadzenie do współczesnego absconditeizmu (Kraków 2020). Specjalizuje się w teologii naturalnej, filozofii człowieka, epistemologii. Jest członkiem Internationale-Ferdinand-Ebner-Gesellschaft.

kowskim. Tischner bardzo poważnie potraktował przedstawioną przez Kołakowskiego interpretację jednej z odsłon tego sporu, a mianowicie XVII-wiecznej kontrowersji pomiędzy jansenistami, z Pascalem na czele, a teologami jezuickimi. Odczytywał jednak pogląd Kołakowskiego jako głos w przekraczającej konkretny historyczny kontekst dyskusji o problemie relacji łaski i wolności. Należy podkreślić, że spór ten odbywał się „w jedną stronę”: Tischner omawiał i krytykował poglądy Kołakowskiego. Dlatego właśnie mówić należy o sporze Tischnera z Kołakowskim, nie zaś o sporze Tischnera i Kołakowskiego. Nie stanowi to jednak przeszkody, by odczytać ich teksty jako prezentację dwóch wchodzących w grę stanowisk, które można i należy poddać ocenie. 
W niniejszym tekście przedstawię w zarysie początek i istotne elementy historii sporu o łaskę i wolność. Zarys historii konieczny jest do tego, aby nakreślić tło dla interesującej nas odsłony sporu. Zarówno Kołakowski, jak i Tischner nawiązują do poglądów uczestników dawnych odsłon tego sporu i proponują rozwiązania, które można pojąć jedynie wówczas, gdy rozumie się rozwiązania przedstawione wcześniej. Zarysowanie tła pozwoli też pokazać nieporozumienia i nadinterpretacje, które pojawiają się zwłaszcza w dotykających tych zagadnień tekstach Kołakowskiego. Następnie przedstawię poglądy interesujących nas myślicieli: rekonstrukcję XVII-wiecznego sporu między jansenistami i molinistami dokonaną przez Kołakowskiego, który sugeruje, iż rozwiązaniem, za jakim w tym sporze opowiedział się Kościół katolicki, był semipelagiznim, oraz krytykę poglądów Kołakowskiego ze strony Tischnera i rozwiązanie zaproponowane przez tego ostatniego, które utrzymane jest w duchu (poprawnie zinterpretowanej) nauki św. Augustyna. Na koniec spróbuję rozstrzygnąć ten spór, pokazując przy tym, w jaki sposób można by spróbować pogodzić stanowiska Kołakowskiego i Tischnera, oraz wskazać konsekwencje tego sporu dla innych niż teologia dziedzin myślenia.

Spór dotyczący relacji między łaską i wolnością nie jest jedynie wąskim i mało znaczącym sporem o jeden $z$ wielu elementów dziedzictwa chrześcijańskiej teologii. Choć zakorzeniony jest w teologii, przekłada się na wiele istotnych zagadnień związanych zarówno z myśleniem o wychowaniu, jak i z myśleniem o polityce. Właśnie dlatego spór ten może zainteresować także filozofa ${ }^{1}$. Zrozumienie wchodzących $\mathrm{w}$ grę teologicznych pojęć i całego teologicznego „zaplecza” sporu jest konieczne, aby móc podjąć dyskusję nad tematami należącymi do filozofii wychowania i filozofii polityki.

1 Tischner sugeruje zresztą, że doświadczenie łaski nie jest wyłącznie domeną badania teologicznego. Teologia dotyka bowiem tylko jednej, „nadprzyrodzonej”, strony tego pojęcia. Łaska posiada jednak także stronę doświadczeniową, dlatego „doświadczenie łaski może, a nawet musi stać się tematem filozofii” (J. Tischner, Zarys filozofii człowieka dla duszpasterzy i artystów, w J. Tischner, Myślenie w żywiole piękna, Kraków 2013, s. 291). 
O znaczeniu tego sporu dla współczesności, nawiązując do książki Kołakowskiego Bóg nam nic nie jest dłużny ${ }^{2}$, tak pisał Tischner: „Książka ma adresata. Jest nim człowiek współczesny, który przeszedł przez doświadczenia totalitaryzmu i niesie w swej duszy pascalowski konflikt między zaufaniem do człowieka a niewiarą w człowieka”. I pytał: „Więc jak to jest: wierzyć czy nie wierzyć w człowieka?"3 Tischner zauważał także: „Zdaniem Kołakowskiego, konflikt jansenistyczno-jezuicki jest w jakiejś mierze nadal aktualny. Czy po wszystkim, czego doświadczyliśmy w naszym stuleciu, mamy podstawy do zaufania człowiekowi? Nasze poznanie człowieka rodzi rozpacz. Kto jednak popadł w rozpacz z powodu człowieka i zaufał wyłącznie Bogu, niech wie: Bóg nam nic nie jest dłużny. Po której stanąć stronie?"” W niniejszym tekście pójdziemy śladem tego pytania. Uzupełnimy je jednak o inne pytanie. Brzmi ono: po której stronie stanąć - Kołakowskiego czy Tischnera? Odpowiedź na to pytanie jest o wiele ważniejsza niż na pierwszy rzut oka mogłoby się wydawać.

\section{Początek sporu}

Spór św. Augustyna z poglądami Pelagiusza stanowi począatek kontrowersji, której jedna $\mathrm{z}$ ostatnich odsłon jest przedmiotem naszego zainteresowania ${ }^{5}$. Problem $z$ tym sporem polega na tym, że nie do końca wiadomo, jakie tak naprawdę były poglądy Pelagiusza. Nie wiadomo także, czy krytyka ze strony Augustyna dobrze trafiała w to, co faktycznie głosił Pelagiusz ${ }^{6}$. Tischner uważa jednak, że można potraktować pelagianizm

2 L. Kołakowski, Bóg nam nic nie jest dłużny. Krótka uwaga o religii Pascala i o duchu janseni$z m u$, Kraków1994.

${ }^{3}$ J. Tischner, Szukając mistrzów naszej wiary, w: J. Tischner, Ksiądz na manowcach, Kraków 1999, s. 236.

4 J. Tischner, Szukając mistrzów naszej wiary, dz. cyt., s. 236-237.

${ }^{5}$ Najlepszym opracowaniem historii sporu o łaskę i wolność, do którego zresztą Tischner wprost nawiązywał, jest: D. Oko, Łaska i wolność. Łaska w Biblii, nauczaniu Kościoła i teologii współczesnej, Kraków 1997.

6 Tischner tłumaczy: „Niezależnie od tego, co na temat łaski myśleli Pelagiusz i Augustyn, paradygmat jest ważny, tak jak dla rzeki ważne są oba jej brzegi. Gdyby takiego paradygmatu nie było, 
i augustynizm jako paradygmaty myślenia o łasce w tradycji chrześcijańskiej. Traktując poglądy Pelagiusza w taki właśnie sposób, filozof twierdzi, że właściwą intencją Pelagiusza było przeciwstawienie się taniemu, „bezwysiłkowemu” chrześcijaństwu. Pelagiusz dążył do odnowy duchowej opartej na rygoryzmie moralnym. Jako duszpasterz i kaznodzieja starał się przede wszystkim wychowywać swoich słuchaczy. Zdaniem Pelagiusza, któremu przyświecała grecka idea paidei - samodoskonalenia człowieka - człowiek ma dążyć do doskonałości, a filozofa i religia powinny mu pokazywać drogę i cel.

Wedle Tischnera Pelagiusz uważał, że człowiek ma możliwość życia bez grzechu i osiągnięcia zbawienia, ponieważ został stworzony na obraz Boży. Zdolność do rozwijania się i dotarcia do celu, jakim jest zbawienie, jest swoistym dynamizmem, w jaki został wyposażony człowiek. Łaska przyniesiona przez Jezusa Chrystusa nie jest konieczna do zbawienia, lecz działa jedynie jako pouczenie. Grzech nie przekreślił danej człowiekowi na początku możliwości zbawienia, lecz stanowił jedynie zły przykład, który utrudnił drogę do osiągnięcia zbawienia. Jak podkreśla Tischner, istotne jest to, że poglądy Pelagiusza przeciwstawiały się manicheizmowi. Pelagiusz sądził, że manicheizm wtrąca człowieka w fatalizm, czyniąc go biernym obserwatorem zła dziejącego się w świecie. W koncepcji Pelagiusza człowiek nie jest skazany na bierne obserwowanie zła, lecz ma możliwość angażowania się po stronie dobra ${ }^{7}$.

Pisząc o Pelagiuszu, Gerhard. L. Müller zauważa, że był on „w gruncie rzeczy bardziej religijnym gorliwcem niż głębokim myślicielem teologicznym". Zdaniem Müllera wbrew temu, co przypisywał mu Augustyn i co zwykła przypisywać mu tradycja teologiczna, nie odrzucał łaski. Zdawał sobie sprawę, że człowiek zostaje zbawiony przez łaskę. Co ważne, pojmował ją jako naturalną zdolność czynienia dobra, nawet jeśli uważał Jezusa za wzór do naśladowania. Jednakże nie rozumiał słowa „wzór” w dzisiejszym moralistycznym sensie. Zdaniem Pelagiusza - podkreśla

to trzeba by go wymyśleć" (J. Tischner, Podglądanie Pana Boga, w: J. Tischner, Ksiądz na manowcach, dz. cyt., s. 255).

7 Zob. J. Tischner, Spór o istnienie człowieka, Kraków 2011, s. 162-164. 
Müller - wiara jest wspierana przez łaskę. Chodzi tu jednak o taki rodzaj wsparcia, który ogranicza się „do ułatwienia poznania i łatwiejszego dokonywania moralnego dobra" .

Myśl Pelagiusza miała swoje konsekwencje w dziedzinie poglądów na wychowanie. Według niego chrześcijaństwo jest religią przeznaczoną dla dorosłych. Dla dziecka, które nie jest niczemu winne, a w związku z tym nie potrzebuje zgładzenia grzechu, chrzest to jedynie inicjacja w rzeczywistość Bożego królestwa. Grzech pierworodny nie zmienił kondycji ludzkiej natury. Biblijny Adam nie skaził natury grzechem, lecz jedynie dał ludziom zły przykład ${ }^{9}$. Pelagiusz podkreśla znaczenie aktu stworzenia. Podarowana człowiekowi w tym akcie łaska nie została unieważniona ani zatarta w wyniku grzechu pierworodnego, natura nie została zniszczona, lecz jedynie narażona na zły przykład, z którego wpływu można i trzeba się wyzwolić dzięki pomocy Chrystusa. Można stwierdzić, że istotą pelagianizmu jest przekonanie, że człowiek w sprawach własnego zbawienia może naprawdę bardzo wiele, o ile nie wszystko. Gwarantem tej „mocy” jest zaś „stworzenie” rozumiane jako wyposażenie człowieka w zdolność do działania. Ostatecznym dawcą zbawienia jest więc Bóg. Zbawienie bardziej wiąże się jednak z aktem stworzenia, niż z osobą i zbawczą misją Jezusa Chrystusa.

Przeciwko tym, nazbyt jego zdaniem optymistycznym, poglądom wystąpił św. Augustyn ${ }^{10}$. Podkreślał, że łaska, inaczej niż sądzą pelagianie, nie jest jedynie możliwością niegrzeszenia otrzymaną od Boga w połączeniu wraz wolną wolą. Łaska nie jest także jedynie dobrym

8 G. Müller, Dogmatyka katolicka, tłum. W. Szymona, Kraków 2015, s. 797.

9 Por. V. Grossi, L. Ladaria, P. Lécrivain, B. Sesboüé, Historia dogmatów, t. 2: Człowiek i jego zbawienie, Kraków 2001, s. 252.

10 Ten polemiczny rys poglądów Augustyna jest niezwykle istotny. Zwraca na to uwagę Agnieszka Kijewska, gdy pisze: „Augustyńskie nauczanie o łasce, dominujące zwłaszcza w późnym okresie jego twórczości, należy rozpatrywać w kontekście całości jego myśli, którą ukształtowały polemiki doktrynalne z manichejczykami, akademikami, platonikami, pelagianami czy donatystami. Ostatnie jego dzieła, będące odpowiedzią na konkretne problemy, z którymi do niego się zwracano, często prowadziły do różnych nadinterpretacji” (A. Kijewska, Augustyńskie dziedzictwo, w: Przewodnik po filozofii średniowiecznej. Od św. Augustyna do Joachima z Fiore, red. A. Kijewska, Kraków 2012, s. 36.) 
przykładem. Zdaniem biskupa Hippony łaska jest niezbędną pomocą do tego, aby nie popełniać grzechów. Uważał, że w wyniku grzechu pierworodnego natura ludzka została zraniona, zniszczona, udręczona i zagubiona. Ten pogląd przekłada się na zupełnie inny niż wynikający z pelagianizmu obraz procesu wychowania. Augustyn uważa, że samo wychowanie nie wystarczy do tego, aby naprawić naturę. Konieczna jest stała, nadprzyrodzona pomoc ze strony Boga.

Należy jednak podkreślić, że Augustyn nie przeciwstawia łaski i wolności. W jednym $\mathrm{z}$ ważnych pism poświęconych temu zagadnieniu cytuje słowa św. Pawła: „nie ja sam, ale łaska Boża ze mną”" ${ }^{11}$ Według niego to „Na pewno my jesteśmy podmiotem naszych czynów, lecz Bóg bardzo skutecznie umacniając naszą wolę, jest ich przyczyną" ${ }^{12}$. Łaska nie unieważnia ani nawet nie umniejsza ludzkiej wolności. Człowiek osiąga i realizuje możliwości swej wolności poprzez łaskę, a nie na odwrót. Augustyn pisze: „Wola ludzka bowiem nie przez wolność osiąga łaskę, lecz raczej przez łaskę wolność, ażeby pozostać w rozkosznej stałości i niezachwianej sile" ${ }^{13}$. Według niego Adam został stworzony w łasce Boga. Właśnie dlatego posiadał kondycję różną od naszej pod trzema względami: mógł nie umrzeć, nie znał walki ciała przeciw duchowi, posiadał możliwość niegrzeszenia. Zgrzeszył jednak, a w konsekwencji pociągnął za sobą cały rodzaj ludzki. Dlatego nikt nie rodzi się w kondycji niewinnego Adama, lecz w kondycji istoty dotkniętej grzechem. Wyzwolenie z tego grzesznego dziedzictwa następuje dzięki łasce Chrystusa. Łaska udzielona Adamowi była niezbędną pomocą - bez niej Adam nie mógł wytrwać w dobru, w którym został stworzony. Tak pojętą łaskę Augustyn nazywał: adiutorium sine qua non. Łaska przyniesiona przez Chrystusa ludziom dotkniętym skutkami grzechu pierworodnego daje nie tylko moc wytrwania, ale samo wytrwanie - innymi słowy pomoc, przez którą możemy wytrwać. Ten rodzaj łaski Augustyn nazywał

11 Zob. św. Augustyn, Łaska a wolna wola, w: Augustyn, Łaska, wiara, przeznaczenie, PoznańWarszawa-Lublin 1970, s. 118.

12 Św. Augustyn, Łaska a wolna wola, dz. cyt., s. 134.

13 Św. Augustyn, Nagana i łaska, w: św. Augustyn, Łaska, wiara, przeznaczenie, dz. cyt., s. 180. 
adiutorium $q u o^{14}$. Wedle Augustyna laska jest zatem nie tylko pomocą, ale warunkiem wszelkiego możliwego dobra, jakie dzieje się za sprawą ludzkich podmiotów. Teolog wydaje się więc zajmować o wiele bardziej pesymistyczne niż pelagianie stanowisko w kwestii ludzkiej natury i jej stanu po grzechu pierworodnym. Odwrotną stroną tego pesymizmu jest absolutne zaufanie pokładane w Bożej łasce.

\section{Semipelagianizm ${ }^{15}$}

Synod w Kartaginie, który odbył się w roku 418, potępił pelagianizm $^{16}$. Potwierdził konieczność łaski Bożej nie tylko dla odpuszczenia grzechów, ale również dla możliwości ich niepopełniania. W myśl orzeczeń tego synodu łaska jest udzieleniem mocy, nie tylko dobrym przykładem dla człowieka. W odpowiedzi na wywołany potępieniami przez synod w Kartaginie kryzys pelagianizmu, lecz być może jeszcze mocniej jako wyraz niezgody na niektóre z twierdzeń Augustyna na temat łaski, zrodził się nurt zwany semipelagianizmem. Twórcami tego nurtu byli mnisi z Prowansji, uczniowie Jana Kasjana (wśród z nich Prosper z Akwitanii). Semipelagianie odrzucali skrajne tezy Pelagiusza. Przyjmowali Augustyńską tezę o konieczności łaski. Uważali jednak, iż łaska idzie w ślad za postanowieniem woli. Ich zdaniem wola wyprzedza łaskę. Metaforycznie można ująć rzecz w ten sposób, iż wola ludzka niejako

14 Por. V. Grossi, L. Ladaria, P. Lécrivain, B. Sesboüé, Historia dogmatów, dz. cyt., s. 257.

15 Zgrabną definicję tego stanowiska prezentuje Müller: „Semipelagianizm jest powszechnie od XVI wieku przyjmowanym określeniem powstałej w Afryce i w południowej Galii reakcji na naukę Augustyna o absolutnej konieczności łaski do każdego zasługującego uczynku" (G. Müller, Dogmatyka katolicka, dz. cyt., s. 798).

16 Oto kilka istotnych orzeczeń tego synodu: „[... ] jeśli ktoś twierdzi, iż łaska Boża, która usprawiedliwia człowieka przez Pana naszego Jezusa Chrystusa, ma znaczenie tylko dla odpuszczenia grzechów już popełnionych, natomiast jest bez znaczenia, gdy chodzi o pomoc w ich niepopełnianiu - niech będzie wyłączony ze społeczności wiernych” (kanon 3); „[...] jeśli ktoś twierdzi, że ta sama łaska Boża przez Jezusa Chrystusa, Pana naszego, o tyle tylko nas wspomaga, by nie grzeszyć, o ile za jej sprawą poznajemy i pojmujemy przykazania pouczające, czego pragnąć, a czego unikać należy, nie otrzymujemy zaś przez nią także chęci oraz mocy czynienia tego, co wiemy, że czynić trzeba - n.b.w." (kanon 4) (cyt. za: Breviarium fidei. Wybór doktrynalnych wypowiedzi Kościoła, opracowali S. Głowa i I. Bieda, Poznań 1997, s. 286). 
szuka lekarza, ponieważ człowiek uświadamia sobie, że sam z siebie nie może niczego uczynić.

Poglądy semipelagian były osadzone w ich sposobie życia. Do ich grona należeli głównie pobożni mnisi. Modlitwę i umartwienia, które stanowiły nieodłączny element ich życia i praktyki wiary, uważali za akty przygotowujące do przyjęcia łaski. Sądzili, że kto dużo się modli i oddaje umartwieniom, na pewno otrzyma łaskę wiary. Ich poglądy można streścić w haśle: „człowiek zaczyna, a Bóg kończy”. Semipelagianie stali także na stanowisku, że człowiek może wytrwać w wierze dzięki swojej woli.

Przeciwko poglądom semipelagian wypowiedział się w roku 529 synod w Orange ${ }^{17}$. Ojcowie tego synodu podkreślali, że początek wiary także nie jest owocem czysto ludzkich wysiłków. Nawet jeśli człowiek wchodzi na drogę nawrócenia i, używając metafory semipelagian, zaczyna poszukiwać lekarza, dzieje się tak dlatego, że działa już w nim łaska. To sama łaska sprawia, że człowiek zaczyna o nią prosić. A zatem nie jest tak, że „człowiek zaczyna, a Bóg kończy”. Bóg jest także u początku. Wyzwolenie nie jest jednorazowym aktem, który dokonuje się na początku, lecz jest dawane człowiekowi stale, w procesie uświęcenia.

Ten sam synod w Orange krytycznie potraktował także niektóre elementy doktryny św. Augustyna. Odrzucono jego przekonanie, że Bóg daje łaskę, komu chce, ale nie daje jej wszystkim. Augustyn uważał, że w wyborze do zbawienia tylko niektórych nie ma żadnej niesprawiedliwości. Udzielanie łaski jedynie wybranym jest pochodną Bożej transcendencji - jesteśmy zbyt mali, by oceniać w tym Boga albo Mu się

17 W jego orzeczeniach czytamy między innymi: „Jeśli ktoś twierdzi, że łaska Boża może być udzielona na prośbę ludzką i że zaś nie sama łaska sprawia, iż o nią prosimy, ten sprzeciwia się prorokowi Izajaszowi oraz Apostołowi mówiącym tak samo: «Znaleźli mnie ci, którzy mnie nie szukali. Objawiłem się tym, którzy nie pytali o mnie» [Iz 65,1; Rz 10, 20]” (kanon 3); „Jeśli ktoś twierdzi, że jak wzrost, tak i początek wiary i sama chęć wierzenia - dzięki której wierzymy w Tego, co usprawiedliwia grzesznika, i dochodzimy do odrodzenia przez chrzest św. - dzieje się nie z daru łaski, tj. przez natchnienie Ducha Świętego naprowadzającego wolę naszą od niewiary do wiary, od złego życia do pobożności, lecz mamy to w sposób naturalny, ten sprzeciwia się apostolskiej nauce [...]" (kanon 5) (cyt. za: Breviarium fidei, dz. cyt., s. 298). 
przeciwstawiać ${ }^{18}$. Zdaniem Augustyna Bóg nie skazuje nikogo na potępienie. Po prostu nie pomaga pewnym ludziom i zostawia ich na pastwę popełnionych przez nich grzechów. Nie oznacza to jednak, że ktokolwiek jest zmuszony do czynienia zła. Nie jesteśmy w stanie poznać racji, jakie Bóg ma dla tego typu działań. Św. Augustyn sądzi, iż racje te staną się dla nas jawne w życiu przyszłym. Odrzucenie przekonania, że Bóg daje łaskę, komu chce, ale nie daje jej wszystkim, jest dowodem na to, że Kościół nie przyjmował bezkrytycznie poglądów Augustyna ${ }^{19}$. Szedł jednak tropem jego myśli, mając istotne ku temu powody.

\section{Nauka Augustyna o łasce i wolności oraz jej (nad-) interpretacje}

Z punktu widzenia współczesnych badań nad nauką św. Augustyna myśliciel ten zdaje się $\mathrm{w}$ sposób szczególnie trafny godzić problem dwóch wolności - Boga i człowieka. W historii teologii często wybierano jedną „stronę" i zawężano horyzont. Augustyn potrafił zharmonizować istotne elementy, które muszą zostać wzięte pod uwagę, jeśli chce się skonstruować odpowiadającą biblijnym danym i jednocześnie przekonującą teologię łaski i wolności.

W myśli Augustyna cały problem jest osadzony chrystologicznie, a zatem ma wymiar historyczno-zbawczy, nie zaś czysto abstrakcyjny. Ta właśnie cecha zostanie utracona w biegu dziejów omawianej relacji

18 Św. Augustyn pisze: „Nie umiem odpowiedzieć na pytanie, dlaczego Bóg obdarowanym przez siebie miłością potrzebną do życia chrześcijańskiego nie dał wytrwałości. Odpowiadam: Nie wiem. Nie zarozumiale, ale znając moje słabe możliwości, słucham słów Apostoła: «O człowiecze! Kim jesteś, byś mógł Bogu w sporze stawić czoło?» (Rz 9, 20). I dalej: «O głębokości bogactw, mądrości i umiejętności Bożej! Jakże niepojęte są sądy Jego i niezbadane drogi Jego» (Rz 11,33). Dziękujmy zatem, gdy łaskawie raczy nam odsłonić swe zamiary. Jeśli zaś zakrywa je przed nami, nie szemrajmy przeciw Jego postanowieniom, lecz bądźmy przekonani, że i to jest dla nas najbardziej zbawienne” (św. Augustyn, Nagana i łaska, dz. cyt., s. 180).

19 Louis Bouyer zaznacza: „Ważne jest jednak, aby przypomnieć właśnie tutaj, że Kościół nigdy nie potwierdzał w żaden sposób sformułowań i koncepcji Augustyna dotyczących predestynacji (przedwiecznego wybrania niektórych do zbawienia suwerenną decyzją Boga i opuszczenia tzw. massa damnationis, skazanej na potępienie) oraz jej konkretnych, historycznych i psychologicznych skutków" (L. Bouyer, Duch Święty Pocieszyciel, tłum. A. Liduchowska, Kraków 1998, s. 275). 
między wolnością a łaską. Augustyn przejawia także mądry szacunek do Tajemnicy. Twierdzi, że człowiek nie może zgłębić nieprzeniknionych zamysłów Boga. Choć sam Augustyn błędnie wykorzystał tę tezę do obrony tezy o ograniczonym zasięgu łaski, sama ta teza nie musi pociągać za sobą tego typu konsekwencji.

Dla Augustyna łaska jest relacją, nie zaś „,rzeczą”, którą Bóg może dać człowiekowi bądź której może mu odmówić. Łaska nie jest dającym się zreifikować „pośrednictwem”, istniejącym niezależnie od czegokolwiek innego, lecz raczej przejawem życzliwości Boga w stosunku do człowieka życzliwości, która ma charakter osobowy. Odpowiedź ze strony człowieka także musi mieć charakter osobowy. Augustyn pokazuje, że Bóg podtrzymuje człowieka w wolnym działaniu tak, jak podtrzymuje go w bycie. Można odrzucić pomoc ze strony Boga, przeciwstawić się dawanemu przez Niego ukierunkowaniu. Traci się wówczas „wolność”, lecz nie traci się „wolnej woli” - to rozróżnienie jest niezwykle istotne dla Augustyna. Jego zdaniem wolna wola jest pośredniczką wolności. Posługiwanie się wolną wolą pozwala wolności przyswoić sobie z biegiem czasu dar Boga im bardziej wolność umacnia się w Bogu, tym mniej poddana jest zmienności wolnej woli. Można powiedzieć, że dla Augustyna wolność nie tyle jest możnością dokonywania wyborów, ile raczej miłością do dobra - miłością stałą, której gwarantem jest skierowanie woli w stronę dobra, jakim jest Bóg. Łaska jest pomocą dla wolnej woli człowieka, dając jej konkretną możliwość stania się wolnością. Adam w chwili grzechu utracił wolność, nie utracił jednak wolnej woli. Łaska nie zastępuje wolnej woli, lecz sprawia, że jest ona w stanie na nowo korzystać z wolności. Te dwa czynniki nie znajdują się na tym samym planie, jak „konie ciągnące ten sam wóz". W dobrym działaniu człowieka wszystko jest z łaski i jednocześnie wszystko jest $\mathrm{z}$ wolności. W ten sposób można rozwiązać ten na pierwszy rzut ona nierozwiązywalny konflikt pomiędzy tymi dwiema siłami ${ }^{20}$.

W związku z takim pojmowaniem łaski, wolności oraz relacji pomiędzy nimi zmienia się także pojmowanie wychowania. Staje się ono ukierunkowywaniem. Wychowanie wywiera realny wpływ na człowieka.

20 Por. V. Grossi, L. Ladaria, P. Lécrivain, B. Sesboüé, Historia dogmatów, dz. cyt., s. 262-264. 
Nie polega on jednak na warunkowaniu. Zadaniem wychowawcy jest pomoc w wyzwoleniu wolności. Dobra wola bowiem jest najpierw mała i jeszcze niezdolna (parva et invalida), potem staje się wielka i zdolna do wykonywania tego, czego pragnie (magna et robusta). Do tego stopniowego wyzwalania dostosowuje się łaska, która także staje się mała lub wielka. Wyzwolenie człowieka nie dokonuje się w jednym momencie, lecz wymaga czasu ${ }^{21}$.

Augustyńska teologia łaski i wolności jest wynikiem charakterystycznego dla biskupa Hippony sposobu podchodzenia do zagadnień teologicznych. Müller tak opisuje to podejście: „Augustyn jest typowym teologiem egzystencjalnym, który w swym myśleniu nie posługuje się abstrakcyjnymi, spekulatywnymi pojęciami późniejszej teologii, lecz trzyma się konkretnego, historycznego porządku starochrześcijańskiej tradycji biblijnej. Dlatego też nie zna abstrakcyjnego pojęcia natury ludzkiej (natura pura), które w istocie nigdy nie było zrealizowane, lecz analizuje człowieka w konkretnych sposobach egzystencji, których według Biblii rodzaj ludzki doświadczał i nadal doświadcza jako realne sytuacje zbawienia albo potępienia”22. Właśnie to „egzystencjalne”, nie zaś „scholastyczne" podejście do problemu relacji między łaską i wolnością było pierwszym z najbardziej istotnych powodów, dla których wracano do poglądów Augustyna. Drugim, niemniej istotnym, było przekonanie, że Augustyn, mimo iż nie ustrzegł się błędów, zasadniczo poprawnie oddał to, co o łasce i wolności ma do powiedzenia chrześcijańskie Objawienie.

Tropem myśli Augustyna idzie bez wątpienia dekret Soboru Trydenckiego o usprawiedliwieniu (wokół poglądów Augustyna toczyły się soborowe batalie dotyczące problemu usprawiedliwienia). Orzeczenia zawarte w tym dekrecie podkreślają bezinteresowność daru Bożego. Choć dekret ten miał charakter polemiczny, przedstawiał nauczanie „zrównoważone i ogólnie rzecz biorąc spokojne, doktryny o usprawiedliwieniu przez łaskę, z której czyni centralny rozdział dogmatyki katolickiej”23.

21 Por. V. Grossi, L. Ladaria, P. Lécrivain, B. Sesboüé, Historia dogmatów, dz. cyt., s. 264.

22 G. Müller, Dogmatyka katolicka, dz. cyt., s. 797-798.

23 Por. V. Grossi, L. Ladaria, P. Lécrivain, B. Sesboüé, Historia dogmatów, dz. cyt., s. 288, 306-307. 
Ze względu na interesującą nas dyskusję pomiędzy Tischnerem i Kołakowskim bardziej istotny jest dla nas następny ważny etap tego sporu, a mianowicie kontrowersja wokół jansenizmu. Korneliusz Jansen, od którego łacińskiego imienia bierze nazwę ta kontrowersja, w historii myśli stanowi główny punkt odniesienia dla myśli Pascala i symbol zmagania $\mathrm{z}$ teologami jezuickimi ${ }^{24}$. Kluczem do doktryny Janseniusza jest przywoływany wyżej Augustyński traktat Nagana i łaska. Szczególnie istotny jest fakt, że Janseniusz reinterpretuje pierwotne Augustyńskie kategorie, przesuwając nieco akcenty. Wprowadza rozróżnienie na „łaskę wystarczającą" i „łaskę skuteczną”. Znane od Augustyna pojęcie adiutorium sne qua non u Janseniusza staje się „łaską wystarczającą”. Łaska Chrystusa, adiutorium quo, o której pisał Augustyn, u Janseniusza jest „łaską skuteczną".

Dokonane przez Janseniusza przesunięcie akcentów było wynikiem zmian w teologii łaski, które zachodziły już w średniowieczu. Istota tych zmiana leżała w tym, że stanowisko Augustyna przekształcono w dyskusję o wewnętrznej naturze łaski. Janseniusz posuwa ten trend jeszcze dalej. Pyta, w oparciu o co laska jest „wystarczająca” lub „skuteczna”. Zadaje także pytanie o to, co w obliczu tak pojętej łaski, pozostaje jeszcze dla wolności człowieka. Można więc powiedzieć, że Janseniusz czyta Augustyna w duchu przeciwstawienia łaski i wolności. W taki sposób zinterpretowali poglądy biskupa z Hippony także Luter i Kalwin. W myśl tego typu interpretacji łaska jest siłą nie do doparcia dla ludzkiej wolności ${ }^{25}$.

24 Spór ten Kołakowski podsumował w następujący sposób: „W sporze Pascala z jezuitami uderza paradoksalny charakter obu stanowisk. Chodzi w tym sporze o to samo, o co chodzi we wszystkich sporach ideologicznych na obszarze całej historii chrześcijaństwa - o stosunek między skończonym światem doświadczenia a światem nadprzyrodzonym, a więc o sposób, w jaki życie doczesne jest włączone w perspektywę nieskończoności, a w jaki oddzielone od niej, o charakter owej delikatnej granicy, na której nasz świat ociera się o rzeczywistość niewiadomą, niezwiązaną przestrzenią i czasem" (L. Kołakowski, Banał Pascala, w: L. Kołakowski, Chrześcijaństwo, wstęp, wybór i opracowanie, Kraków 2019, s. 237-238).

${ }^{25}$ Por. V. Grossi, L. Ladaria, P. Lécrivain, B. Sesboüé, Historia dogmatów, dz. cyt., s. 258. W bulli Klemensa XI Unigenitus, będącej odpowiedzią na jansenizm, zostały potępione między innymi następujące tezy: „Kiedy Bóg chce duszę zbawić, wówczas Jego wola osiąga skutek niechybny, niezależnie 
Jansenizm jest augustynizmem, lecz znacząco zmodyfikowanym. Jest daleko idącą, dokonaną pod wpływem średniowiecznych przesunięć, nadinterpretacją myśli św. Augustyna. Augustyn ukazywał bowiem przede wszystkim współdziałanie łaski i wolności. Uczynił to, określając łaskę jako pomoc (adiutorium, auxilium) dla wolnej woli, unikał zaś pokazywania jej jako konkurencji wobec ludzkiej wolności. Przesunięcia, które wprowadził Janseniusz, sprawiły, że nie było możliwe ujęcie relacji między łaską i wolnością w sposób, jaki odpowiadałby oryginalnemu augustyńskiemu ujęciu tego zagadnienia.

\section{Semipelagianizm według Kołakowskiego}

Kołakowski intepretuje XVII-wieczny jansenizm nie tylko jako chęć uporania się z nierozwiązywalnymi tajemnicami chrześcijaństwa, lecz także jako reakcyjny wzorzec chrześcijańskiej wiary i desperacką próbę zażegnania „złowrogiej groźby kiełkującego Oświecenia” ${ }^{26}$. Jego zdaniem myśl ludzka porusza się i musi poruszać między tymi dwiema skrajnościami, jakimi są pelagianizm (w okresie, o którym pisze, szczególnie istotną wersją pelagianizmu był molinizm - a zatem poddawana namiętnej krytyce przez Pascala teologia jezuicka) i augustynizm (jansenizm jest zdaniem Kołakowskiego nową jego odsłoną). Nieuchronność poruszania się między dwiema skrajnościami w myśleniu o relacji łaski i wolności Kołakowski wyraża cytatem z pism Pierre’a Bayle’a: „Tak marna jest dola ludzka, że światła, co go od jednego zła uwalniają, wtrącają go w inne"27.

od miejsca i czasu. [...] Kiedy Bóg chce dusze zbawić i porusza ją wewnętrznym dotknięciem swej łaski, wówczas żadna wola ludzka Mu się nie oprze” (cyt. za: Breviarium fidei, dz. cyt., s. 339).

${ }^{26}$ Myśl Pascala, zakorzenioną w jansenizmie, Kołakowski określa jako „anty-Oświecenie”. Według niego u Pascala „rozdarcie między «światem» w pejoratywnym znaczeniu chrześcijańskim i dziedziną wiary jest nieprzekraczalne; te dwie rzeczywistości nie mają miejsca spotkania w sensie intelektualnym, moralnym i ontologicznym [...]" (L. Kołakowski, Zaproszenie od Pana Boga na biesiadę. Dialog XVII-wieczny, w: L. Kołakowski, Czy Pan Bóg jest szczęśliwy i inne pytania, wybór i układ Z. Mentzel, Kraków 2009, s. 24).

${ }^{27}$ L. Kołakowski, Bóg nam nic nie jest dłużny, dz. cyt., s. 10. 
Istotę sporu między tymi dwoma stanowiskami można zawrzeć w pytaniu, czy przyczyniamy się do naszego zbawienia, a jeśli tak, to w jaki sposób. Zdaniem Kołakowskiego Kościół, potępiając jansenizm, potępiał samego św. Augustyna, choć tego otwarcie nie oznajmił ${ }^{28}$. Kołakowski sugeruje, że istniały ważkie racje, dla których Kościół musiał się pozbyć części dziedzictwa św. Augustyna, jeśli chciał zachować swoją potęgę. Jego zdaniem Kościól, kształtując swoje nauczanie, praktycznie przyjął wówczas jezuicką (wedle Kołakowskiego semipelagiańską) doktrynę w kluczowych kwestiach grzechu pierworodnego, łaski i predestynacji. Gdyby Kościół w tym czasie przyjął teologię augustyńsko-jansenistyczną za podstawę działalności edukacyjnej, „wkroczyłby na drogę do samozagłady"29.

Augustyńsko-jansenistyczna teologia zawiera zdaniem Kołakowskiego tezy, że:

1) jesteśmy beznadziejnie zepsuci, dlatego możemy czynić tylko zło;

2) łaska jest niezbędna, gdy zaś została dana, działa niezawodnie;

3) łaska jest zarówno warunkiem koniecznym, jak i wystarczającym dobrego działania;

4) Jezus Chrystus nie mógł umrzeć za wszystkich ludzi - wiedział, kto będzie potępiony, a kto zbawiony - nie rozlewał krwi na darmo ${ }^{30}$.

Zestawienie tych tez z poglądami Augustyna, które zostały omówione powyżej, pokazuje, że tylko ostatnią z nich można znaleźć w pismach biskupa Hippony. Kołakowski błędnie utożsamia tezy Augustyna z tezami Janseniusza. Cała reszta, nawet jeśli jest jansenistyczna, nie jest Augustyńska. Wbrew temu, co twierdzi Kołakowski, Kościół, potępiając jansenizm, nie potępił zatem poglądów Augustyna, lecz tylko jedną z wersji augustynizmu, dość odległą od tego, co głosił sam autor Nagany i łaski.

Sensem tego odrzucenia, jak słusznie wskazuje Kołakowski, było przekonanie, że trudno jest nauczać moralności, jeśli zbawienie człowieka nie ma nic wspólnego z jego postępowaniem. Wówczas bowiem

28 Zob. L. Kołakowski, Bóg nam nic nie jest dłużny, dz. cyt., s. 12.

29 L. Kołakowski, Bóg nam nic nie jest dłużny, dz. cyt., s. 44-45.

30 Zob. L. Kołakowski, Bóg nam nic nie jest dłużny, dz. cyt., s. 46-47. 
traci sens idea odpowiedzialności moralnej. Zawarta w doktrynie jansenistycznej teza o „podwójnej predestynacji” jest zdaniem Kołakowskiego teologicznym wyrazem przeświadczenia Kościoła, iż jest on niezwyciężoną armią Boga - przekonania, że „my, chrześcijanie, jesteśmy pod władzą łaski” oraz iż „mamy ufać Ojcu niebieskiemu, a nie targować się z Nim”. Kołakowski uważa, że był to „teologiczny miecz w rękach Kościoła wojującego”. Gdyby zwyciężyły poglądy Pelagiusza, Kościół przekształciłby się w duchową arystokrację niezdolną do wypełnienia swej misji ${ }^{31}$.

Kołakowski sugeruje, że aż do czasów Kontrreformacji w urzędowym, autorytatywnym nauczaniu Kościoła dominowała augustyńska interpretacja grzechu pierworodnego, łaski i predestynacji ${ }^{32}$. Jego zdaniem Kościół nie odrzucał tych elementów teologicznych, ponieważ doktryna predestynacji odpowiadała dobrze mentalności ludzi, którzy poszukiwali bezpieczeństwa moralnego i którzy potrzebowali przekonania, że są wybrańcami Boga. Nawet jeśli stopniowo dawała o sobie znać libido scien$d i$, to jednak Kościół długo nie decydował się na odrzucenie augustynizmu. Według Kołakowskiego taka teologia dobrze sprawdzała się nie tylko we wczesnym okresie istnienia Kościoła, gdy mógł się on uważać za prześladowaną mniejszość, lecz także wówczas, gdy Kościół znajdował się w rozkwicie swojej potęgi. Przekonanie, że ludzie są z natury źli i zepsuci miało usprawiedliwiać jego zdaniem machinę kościelnego przymusu, której istnienie i stosowanie miało być usprawiedliwione pragnieniem podarowania ludziom zbawienia i zabezpieczeniem społeczeństwa przed zgubnym wpływem tych, którzy skłonni byli obrażać Boga. Istnieje zdaniem Kołakowskiego jakaś „przedustawna harmonia” między teologią Augustyńską a mniej lub bardziej teokratycznymi roszczeniami Kościoła $^{33}$.

31 Zob. L. Kołakowski, Bóg nam nic nie jest dłużny, dz. cyt., s. 49.

32 Trudno się zgodzić $\mathrm{z}$ tym twierdzeniem. Jak ukazałem powyżej, Augustyn dyskutował zagadnienia relacji między wolną wolą a łaską, a także problem predestynacji i wolności człowieka. Nie narzucał jednak rozwiązań. To, co Kołakowski nazywa Augustyńską interpretacją grzechu pierworodnego, nie jest przedmiotem wiary Kościoła ani jego dogmatycznych orzeczeń. Tym bardziej nie było wymuszane przez Kościół przyjmowanie takich tez.

${ }^{33}$ Zob. L. Kołakowski, Bóg nam nic nie jest dłużny, dz. cyt., s. 62-63. 
Wziąwszy pod uwagę przedstawiony powyżej rozwój dyskusji o łasce i wolności, mający miejsce w dziejach teologii, można stwierdzić, że Kołakowski zbyt wielką rolę przypisuje samej osobie, a także (interpretowanym przezeń zresztą w mocno zideologizowanym kluczu) poglądom Augustyna. Bez wątpienia obraz dziejów Kościoła, który trwa przy przesiąkniętym manicheizmem podziale na „dobrych" $i$ „złych” i kanonizuje ten podział w osobie Augustyna, jest bardzo sugestywny. Trudno jednak uznać go za prawdziwy.

Ma jednak Kołakowski rację, twierdząc, że w czasach, o których pisze, Kościół musiał, chcąc, nie chcąc, zmierzyć się z nowymi pytaniami. Najważniejsze z nich dotyczyły tego, czy ludzka natura jest buntowniczką, którą trzeba zniszczyć, czy też czymś, co najwyżej nieco skażonym, co można oswoić, uszlachetnić i naprostować. Konsekwencją tego pytania było inne, dotyczące właściwych metod wychowania. Pytanie to dotyczyło tego, co jest lepszą metodą wychowania: przemoc czy cierpliwa edukacja - o to właśnie toczył się spór pomiędzy jansenistami i zwolennikami teologii jezuickiej. Stawką tego sporu było według Kołakowskiego przystosowanie się chrześcijaństwa do nowej cywilizacji, która rozwijała się potajemnie i dojrzewała od kilku stuleci. Od dłuższego już czasu próbowano rozwiązać te dylematy. Jedną z prób ich rozwiązania były, jak przypomina Kołakowski, teksty Erazma z Rotterdamu. To, co proponował Erazm, nie było jednak teologią par excellence ${ }^{34}$. W teologii konieczne są zdaniem Kołakowskiego jednoznaczne odpowiedzi „tak” albo „nie" na kluczowe pytania, które brzmią:

- czy nasz wolny wybór pomaga nam w zbawieniu?

- czy jest w naszej mocy współdziałać z łaską?

34 Zob. L. Kołakowski, Bóg nam nic nie jest dłużny, dz. cyt., s. 65-66. O poglądach Erazma Kołakowski tak pisał w innym miejscu: „[... ] moralistyka Erazma stanowi najwyraźniej, w XVI stuleciu, «trzecią siłę» świata chrześcijańskiego. Przeciwstawia się luterańskiej nadziei na samoczynne dobrodziejstwa organizacyjnego rozłamu i przeciwstawia się luterańskiej pogardzie dla wszystkich wysiłków «naturalnego» człowieka. Propaguje zarazem wzór życia chrześcijańskiego, które, wbrew obyczajowości kościelnej, nie pomnaża swoich wartości dzięki ceremoniom, obrzędom, uczoności scholastycznej, «uczynkom» rytualnym, ale redukuje się niemal w całości do praktyki moralnej, gdzie zarówno dobra intencja, jak uczynek dobry kojarzą się zawsze jako warunki niezbędne" (L. Kołakowski, Erazm i jego Bóg, w: L. Kołakowski, Chrześcijaństwo, dz. cyt., s. 35). 
Kołakowski sądzi, że jeśli na powyższe pytania odpowiemy „tak”, wówczas staniemy na stanowisku, że zbawienie zależy od naszych wysiłków. W konsekwencji zaś będziemy twierdzić, że musimy uzupełnić Bożą łaskę poprzez własne działanie, a zatem jest ona potrzebna, ale nie jest wystarczająca. Zdaniem Kołakowskiego pociąga to za sobą herezję semipelagiańską. Odpowiedź „nie” prowadzi do tezy, że wszystko, całe nasze działanie, pochodzi od Boga. Takiej właśnie odpowiedzi udzielili, zdaniem Kołakowskiego, zarówno Augustyn, jak i Kalwin oraz, oczywiście, Janseniusz. Jak pisałem powyżej, o ile taką odpowiedź można przypisać dwóm ostatnim, o tyle nie można jej przypisać Augustynowi.

Dylemat ten, mający dalekosiężne konsekwencje, nie został nigdy zdaniem Kołakowskiego rozwiązany, mimo ogromnych wysiłków katolickich teologów. W czasach, o których pisze Kołakowski, konieczne było jego zdaniem jednoznaczne „tak” lub „nie” - konieczna była odpowiedź na pytania: czy jesteś za Atenami czy Jerozolimą, za Bogiem czy za człowiekiem? ${ }^{35}$ Kołakowskie pisze: „Sens kontrowersji wokół łaski wydawał się zupełnie jasny w kategoriach chrześcijańskich, tak edukacyjnych, jak politycznych. Orędownicy bezwarunkowej predestynacji chcieli wzbudzić ducha prawdziwej pobożności jako przeciwieństwa łatwych uczynków"36.

Wedle Kołakowskiego XVII-wieczny spór między jansenistami a molinistami jedynie ujawnił to, co było faktem już od kilku dziesięcioleci: że odrzucenie augustynizmu nieuchronnie musi prowadzić do semipelagianizmu. W grę mogło wchodzić jeszcze jedno rozwiązanie, choć zdaniem Kołakowskiego nie można go było traktować jako uczciwego rozwiązania. Miało ono polegać na mówieniu o tych kwestiach językiem niejasnym i pozbawionym precyzji. Jeśli, jak zdaniem Kołakowskiego należy czynić w teologii, mówi się językiem precyzyjnym, potępienie poglądów kalwińskich nieuchronnie musi się wiązać $\mathrm{z}$ opowiedzeniem się za faktycznym semipelagianizmem, nawet

35 Zob. L. Kołakowski, Bóg nam nic nie jest dłużny, dz. cyt., s. 67.

36 L. Kołakowski, Bóg nam nic nie jest dłużny, dz. cyt., s. 69. 
gdy unika się przywoływania tej nazwy. Potępienie semipelagianizmu, a w związku z tym wybór drogi zapoczątkowanej przez Augustyna, sprawia, że teolog staje się krytpokalwinem, nawet jeśli na poziomie deklaracji odrzuca tan pogląd ${ }^{37}$.

Według Kołakowskiego Kościół przez całe wieki ratował się poprzez używanie dwuznacznego języka teologicznego, jednakże janseniści zmusili go wyboru ${ }^{38}$. Poprzez odrzucenie jansenizmu nastąpiła „deagustynizacja" Kościoła. Kołakowski uważa, że najistotniejszym powodem, dla którego zdecydowano się na ten ruch, było to, iż teologowie katoliccy zrozumieli, że nie można dłużej narzucać dyscypliny i powagi wyższym sferom społeczeństwa. Augustyńska surowość - argumentuje Kołakowski - nie nadawała się do sal balowych i dla bywalców teatrów ${ }^{39}$. W czasach, gdy toczył się XVII-wieczny spór o relację wolności i łaski, żyło wielu libertynów i sceptyków. Aktywni społecznie stali się również deiści, którzy swoje poglądy opierali na nauce i podawali w wątpliwość prawdy zawarte $\mathrm{w} \mathrm{Biblii}{ }^{40}$. Strategia teologów jezuickich, oparta na przejściu na pozycje semipelagiańskie, była zdaniem Kołakowskiego próbą znalezienia dla takich ludzi miejsca w Kościele. Teologowie ci, pisze Kołakowski, nie chcieli wyrzucić tych ludzi poza obręb Kościoła, a przez to skazać ich na wieczne potępienie. Dostosowali więc do nich teologię, aby ich ratować. Co więcej, przyjmując rozwiązanie semipelagiańskie, Kościół dał dowód wielkiej plastyczności, która pozwoliła mu przetrwać w społeczeństwie ulegającym głębokiej mentalnej przemianie. Dzięki wykorzystaniu znanej z dziejów Kościoła sztuki rozróżniania, można było głosić dobrze pasujące do rozwijającego się humanizmu tezy o tym, że natura jest dobra, a w związku z tym należy się z nią solidaryzować,

37 Zob. L. Kołakowski, Bóg nam nic nie jest dłużny, dz. cyt., s. 75.

38 Zob. L. Kołakowski, Bóg nam nic nie jest dłużny, dz. cyt., s. 75-76.

39 To twierdzenie także trudno uznać za przekonujące. W wieku XVII Augustyn cieszył się bowiem wielką popularnością zarówno wśród katolików, jak i protestantów.

40 Przekonanie Kołakowskiego, jakoby deiści opierali swoje poglądy na rodzących się w XVII i XVIII wieku naukach jest niezgodne z faktycznym stanem rzeczy. W poglądach myślicieli, takich jak Collins, Toland czy Tindal nie ma odwołań do nauki, lecz raczej krytyka religii objawionej, teologia naturalna, nauka o rozumie naturalnym i zdrowym rozsądku. 
towarzyszyć jej, poprawiać ją, jednakże bez użycia siły i posługiwania się przymusem $^{41}$.

Kołakowski atakuje jeszcze jeden istotny element teologii jansenistycznej, której przedstawicielem jest dla niego Pascal, a mianowicie chrystocentryzm tej teologii. Jego zdaniem odwoływanie się do osoby i dzieła Jezusa Chrystusa było aktem myślowej desperacji wynikającym z tezy o niepoznawalności Boga. Według Kołakowskiego podkreślanie osadzenia problemu relacji między łaską i wolnością w kontekście chrystologicznym było jedynie ucieczką, nie zaś realnie wchodzącym $\mathrm{w}$ grę rozwiązaniem, ponieważ jest wynikiem radykalnego rozdzielenia wiary i wiedzy ${ }^{42}$. Ostatecznie wydaje się więc, że jedynym sposobem na to, by nie wpaść w sidła będącego konsekwencją pójścia śladem myśli Augustyna fideizmu (co jak sugeruje Kołakowski przydarzyło się Pascalowi), jest zajęcie pozycji semipelagiańskiej. Zdaniem Kołakowskiego przed wyborem między fideistycznie nachylonym augustynizmem a semipelagianizmem stoi także Kościół w naszych czasach ${ }^{43}$. Konsekwencje tego wyboru stają się jednak widoczne także poza obszarem teologii: na gruncie myśli o wychowaniu i o polityce.

${ }^{41}$ Zob. L. Kołakowski, Bóg nam nic nie jest dłużny, dz. cyt., s. 77-78, 80. W innym miejscu filozof tłumaczy: „Kościół rzymski, pragnąc zarówno zachować w arsenale swoich środków ideowych wiarę w wartość postępowania człowieka dla zbawienia (co nadawało większą skuteczność zasadzie posłuszeństwa wobec kościelnych nakazów), jak też ocalić wiarę w absolutną wszechmoc opatrzności a bezsilność człowieka - utrwalił obie te dążności w formułach wewnętrznie niespójnych; niespójność ta doszła do głosu w sporze jansenistów z molinistami, gdzie obie strony odwoływały się do tych samych dogmatów i uchwał dla dowodzenia tez skrajnie przeciwstawnych. Jezuici reprezentowali przy tym wysiłek kościoła zmierzający do utrzymania polityki dostatecznie elastycznej moralnie wobec arystokratyczno-dworskiej klienteli, której zapewniali zbawienie przy pomocy całkiem niekrępujących formalności; janseniści - nade wszystko jednak Pascal - przedstawiali sytuację człowieka jako istoty nie tylko moralnie odpowiedzialnej w sposób bezwzględny za swoje czyny, ale nadto dostępującej sprawiedliwie zabawienia lub odtrąconej na zasadach, o których człowiek nie może mieć najmniejszego pojęcia” (L. Kołakowski, Światopogląd XVII stulecia, w: L. Kołakowski, Chrześcijaństwo, dz. cyt., s. 153).

${ }^{42}$ Zob. L. Kołakowski, Bóg nam nic nie jest dłużny, dz. cyt., s. 184-185. Ten pogląd Kołakowskiego można uznać za wynik nieznajomości tych wątków chrystologicznych odnoszących się do zagadnienia relacji między łaską i wolnością, które są obecne w myśli św. Augustyna.

43 Fideizm także nie jest postawą, którą można by przypisać św. Augustynowi. Być może jednak dałoby się znaleźć go u Janseniusza, a zatem w zmodyfikowanej, a nawet wypaczonej, wersji augustynizmu. 


\section{Tischner}

Tischner nie tylko dyskutuje z tezami Kołakowskiego, lecz także rozwija opartą na augustyńskich podstawach teologię łaski i wolności. Dla Tischnera Kołakowski jest nie tylko historykiem filozofii, który stawia pytania o kwestie same przez się ciekawe. Pisze, że Kołakowski wchodzi w rolę „mistrza wiary”. Na czym polega ta rola? Tischner tłumaczy, że przez swój namysł nad religią Pascala Kołakowski stawia współczesnych czytelników wobec pytania „jaka wiara?” - pytania nie o to, „czy” należy wierzyć, lecz „jak” należy to czynić. To, co Kołakowski pisze o autorze Prowincjałek, pozwala zdaniem Tischnera wczuć się w przeciwieństwa, jakie ujawniają się w wierze Pascala, a także „zrozumieć lepiej własną wiarę i własną niewiarę"44.

Z Kołakowskim Tischner zgadza się co do tego, że w tle poglądów Pascala tkwi jansenizm, w tle jansenizmu pobrzmiewają zaś poglądy św. Augustyna. Temu ostatniemu Tischner przyznaje posiadanie najgłębszej spośród wszystkich ojców Kościoła intuicji dotyczącej przewagi zła nad siłami ludzkimi. Świadom jest jednak wyraźnie, że jansenizm jest radykalizacją nauki św. Augustyna. Wskazuje, że kluczem do jansenizmu jest problem „nieodpartej” łaski, którą daje człowiekowi Bóg, a której istnienie rodzi problem możliwości istnienia wolności w ludzkim podmiocie $^{45}$.

Zgoda pomiędzy Tischnerem i Kołakowskim dotyczy także tego, że pelagianizm pasował do sposobu myślenia ludzi żyjących w nowożytnej Europie. Afirmacja wolności i sceptycyzm co do odpowiedzi na pytania filozoficzne, naukowe i teologiczne, stwarzały dobre warunki do ponownego rozkwitu tej starej idei. Innym powodem skłaniania się w tamtych czasach w stronę pelagianizmu było zdaniem Tischnera to, że ludzkość zaczęła odnosić sukcesy w zwalczaniu zła. Sukcesy te widać było na polu nauki, gospodarki, polityki. Ich konsekwencją były pytania

44 Zob. J. Tischner, Szukając mistrzów naszej wiary, dz. cyt., s. 237.

45 Por. J. Tischner, Szukając mistrzów naszej wiary, dz. cyt., s. 238-239. 
o to, jakie znaczenie mają dla nieba te ludzkie dzieła, a także jak ocenić działania bohaterów nowej cywilizacji ${ }^{46}$.

Tischner nie zgadza się jednak z Kołakowskim co do prawdziwych intencji teologów jezuickich. Jego zdaniem teologom tym chodziło nie tylko o dostosowanie teologii do rozwijającego się społeczeństwa, lecz o prawdę teologiczną o Bogu i człowieku. Ich pragnieniem było według Tischnera znalezienie odpowiedzi na pytania:

- czy Chrystus umarł za wszystkich, czy tylko za wybranych?

- czy można mieć nadzieję, patrząc na człowieka?

- czy mogą mieć nadzieję ci, którzy nie słyszeli o Chrystusie? ${ }^{47}$

Innym przedmiotem niezgody jest teza Kołakowskiego, że wszystkie utopie nowożytne mają $\mathrm{w}$ tle poglądy pelagiańskie. Tischner sugeruje, że o ile można zgodzić się, iż pelagiański optymizm może być powodem mogącej skończyć się katastrofą nieostrożności w podejściu do ludzi oraz że utopie demokratyczna i liberalna mają pelagiańskie tło, o tyle nie zgadza się na traktowanie w kluczu pelagiańskim narodowego socjalizmu i komunizmu. Jego zdaniem te dwie najbardziej krwawe utopie mają raczej manichejską proweniencję ${ }^{48}$.

Tischner inaczej niż Kołakowski interpretuje istotny sens sporu między jansenizmem i molinizmem. Podkreśla także, że według niego spór o łaskę i wolność był sporem o władzę. Choć oficjalnie spierano się o władzę Boga nad światem, to w sporze tym chodziło także o sens władzy w ogóle. Do wzoru Bożej władzy miało się dostosować państwo, a przede wszystkim Kościół. Zdaniem Tischnera w teorii łaski odbija się przynależna epoce „wiedza” o Bogu i samowiedza człowieka. W grę wchodzi tu także wiedza o naturze działania - nie tylko działania Boga na świat, lecz także działania człowieka na człowieka ${ }^{49}$. Tischner uważa, iż w tle sporu o relację między łaską i wolnością było obecne pojmowanie władzy w kategoriach dominacji. Tymczasem, przypomina,

46 Zob. J. Tischner, Szukając mistrzów naszej wiary, dz. cyt., s. 244-245.

47 Zob. J. Tischner, Szukając mistrzów naszej wiary, dz. cyt., s. 245-246.

48 Zob. J. Tischner, Szukając mistrzów naszej wiary, dz. cyt., s. 246-247.

49 Zob. J. Tischner, Podglądanie Pana Boga, dz. cyt., s. 252. 
możliwe jest inne pojmowanie władzy, a mianowicie patrzenie na nią w kategoriach wzajemności. Obydwa stanowiska - tak pelagianizm, jak i jansenizm - niosły ze sobą przekonanie, że Bóg dominuje nad światem tak, jak przyczyna dominuje nad skutkiem. Nawet jeśli chciano uniknąć myślenia w kategoriach „złego fatum”, jakim jest zniewolenie przez grzech, wpadano w objęcia „dobrego fatum”, jakim jest przeznaczenie człowieka do zbawienia ${ }^{50}$. Tymczasem, przypomina Tischner, Bóg objawiony w Biblii nie mieści się w scholastycznym modelu przyczyny. Jest to Bóg, który nie tyle „oddziałuje”, ile wybiera, mówi, objawia się, umiera - a przez to wszystko wzywa do wzajemności, do dialogu ${ }^{51}$.

Najważniejszym obszarem niezgody jest jednak diagnoza postawiona przez Kołakowskiego, zgodnie z którą w czasach sporu jansenistów z molinistami Kościół poszedł drogą semipelagianizmu. Tischner nie zgadza się również z tezą, że nie istnieje możliwość wydostania się z alternatywy: albo augustynizm, albo semipelagianizm. Jego zdaniem rozwiązanie tego dylematu polega na porzuceniu ontologii dominacji.

Tischner tłumaczy, że wybór augustynizmu bądź semipelagianizmu to jedynie zmiana „układu pionków”. Tymczasem chodzi o to, by porzucić „całą szachownicę" ${ }^{2}$. Porzucenie to polega na oczyszczeniu teologii ze szczątków tradycji arystotelesowskiej i przywrócenie jej biblijnego, dialogicznego wymiaru. Umożliwi to ukazanie innej wizji człowieka, a także innej wizji chrześcijaństwa. Co się w niej zawiera? Tischner pisze: „Bóg umarł za wszystkich. Bóg chce, by wszyscy byli zbawieni. Podstawowym sposobem Jego działania jest Słowo. Słowo staje się ciałem i z wolnego wyboru ponosi śmierć za człowieka. Jest w tym

50 Zob. J. Tischner, Szukając mistrzów naszej wiary, dz. cyt., s. 258

51 Zob. J. Tischner, Szukając mistrzów naszej wiary, dz. cyt., s. 247-248.

52 Tischner pisze: „Kołakowski sugeruje, że Kościół poszedł w stronę złotego środka między skrajnością jansenizmu i pelagianizmu, w stronę jakiegoś «semipelagianizmu». Moim zdaniem, to coś innego - to pójście w nowym kierunku. Porzucamy ontologię dominacji. Nie bawimy się w nowe układy pionków, bo nowych układów już nie ma, lecz porzucamy całą szachownicę" (J. Tischner, Szukają mistrzów naszej wiary, dz. cyt., s. 248-249). 
jakaś Siła. Ale jaka? «Siła bezsiły»? Siła Dobra, które «rozprzestrzenia się samo przez się», a nie jak kule bilardowe" ${ }^{\text {"53 }}$.

Zdaniem Tischnera rozumienie relacji między łaską i wolnością, które charakterystyczne jest dla tekstów II Soboru Watykańskiego, umożliwia zapoczątkowanie nowej epoki w rozumieniu chrześcijaństwa. Pozwala bowiem na to, by na nowo określić stosunek Kościoła do cywilizacji, państwa, innych religii, a także na nowo pojąć istotne zadania Kościoła w świecie. Dzięki temu ujęciu możemy uwolnić się od dylematu, z którym teologia próbowała się uporać przez wieki: albo łaska jest ograniczeniem wolności albo wolność jest ograniczeniem łaski. W nowej wizji relacji między tymi rzeczywistościami wolność widzialna jest jako dar łaski. Dzięki takiemu ujęciu możliwe staje się również podkreślenie tego, że wolność jest wartością międzyludzkąa ${ }^{54}$. Aby mówić o tym w sposób zrozumiały i przekonujący, należy zdaniem Tischnera zrezygnować z języka ontologii, a częściowo nawet z języka transcendentalizmu, a sięgnąć po język filozofii dialogu i zawartej w niej filozofii dobra i filozofii wartości $i^{55}$.

Formułując własne rozumienie wolności, Tischner idzie drogą Augustyna - tego, co w Augustyńskiej teologii najlepsze. Widać jednak wyraźnie - ponieważ Tischner próbuje jaśniej wyrazić to, co zawiera nauczanie Kościoła w tej kwestii - że cały Kościół idzie drogą Augustyna, wydobywając z jego myśli o łasce i wolności to, co trafne i najbardziej cenne, usuwając zaś to, co błędne. I choć Tischner nazywa ujęcie kwestii relacji łaski i wolności dokonane przez II Sobór Watykański „nowym”,

53 J. Tischner, Szukając mistrzów naszej wiary, dz. cyt., s. 249.

54 Tischner pisze: „łaska Otwiera na sens. Kto doznał łaski, wie, że dobrze jest łowić ryby, które zaspokajają głód człowieka, ale jeszcze lepiej «łowić» ludzi - istoty, które «nie samym chlebem żyją, ale również słowem wychodzącym z ust Boga». Łaska wznosi człowieka na nowy "poziom życia». Nie niszczy wolności, lecz umożliwia jej istnienie «na nowym poziomie». Dzięki wolności, która stała się «darem łaski», człowiek może być «sobą u siebie». Łaska «kusi» nie tylko tym, że «dobrze jest nie kłamać», ale i tym, że «wspaniale jest» w y b r a ć życie w prawdzie. W niej i poprzez nią sama wolność staje się najwspanialszą, bo najbardziej ludzką "pokusą» człowieka” (J. Tischner, Podglądanie Pana Boga, dz. cyt., s. 275).

55 Zob. J. Tischner, Podglądanie Pana Boga, dz. cyt., s. 275-276. 
to jednak jest to, jak zwykle w dziejach chrześcijaństwa, „nowość” będąca powrotem do dobrze zinterpretowanej i oczyszczonej z błędnych ujęć tradycji.

\section{Rozstrzygnięcie sporu}

Omówiwszy poglądy Kołakowskiego i Tischnera, spróbujmy ukazać możliwość pogodzenia obydwu perspektyw i sformułować wynikające z tego sporu postulaty. Zwróćmy także uwagę na konsekwencje tego sporu w obszarze filozofii wychowania i filozofii polityki.

Kołakowski nie ma racji, twierdząc, że Kościół aż do czasów nowożytności myślał czysto po Augustyńsku - a zatem, że szedł śladem św. Augustyna bezkrytycznie - potem zaś, w wyniku zmiany sytuacji kulturowej porzucił augustynizm na rzecz semipelagianizmu. O ile można zgodzić się, że doktryna Kościoła w kwestii relacji między łaską i wolnością była zasadniczo augustyńska, o tyle należy podkreślić, iż już na samym początku tego sporu odrzucone zostało to, co najbardziej kontrowersyjne w poglądach św. Augustyna, a zatem przekonanie, że łaska jest dawana tylko niektórym. Także kontrowersja między jansenistami a molinistami nie doprowadziła do odrzucenia myśli św. Augustyna. Alternatywa, którą formułuje Kołakowski (albo augustynizm, albo semipelagianizm), jest fałszywa dlatego, że augustynizm jest przezeń interpretowany w duchu jansenistycznym. Kościół wybierał i wybiera trzecie rozwiązanie, a mianowicie przyjmuje augustynizm wolny od błędów związanych z predestynacjonizmem, najlepiej układający relacje między łaską i wolnością.

Należy jednak zgodzić się z Kołakowskim w tym, że praktyka Kościoła często nie szła $\mathrm{w}$ parze $\mathrm{z}$ orzeczeniami dogmatycznymi. Kołakowski słusznie podkreśla, że mimo poprawnie sformułowanych orzeczeń, w praktyce Kościół bywał semipelagiański. Twierdzenie to wydaje się być prawdziwe nie tylko w odniesieniu do Kościoła dawnych wieków, lecz pozostaje aktualne również dziś. Przykłady można by mnożyć, cytując głoszone dziś homilie czy formułowane programy duszpasterskie. 
Tischner także jest świadomy tego niebezpieczeństwa. Sądzi jednak, że nie jesteśmy skazani na poruszanie się między skrajnościami skrajnie pesymistycznego augustynizmu i nawinie optymistycznego pelagianizmu. Nie uważa także semipelagiznizmu za pożądany złoty środek między tymi skrajnościami. Wydaje się, że cały problem leży w tym, z czym Kościół próbuje się uporać od samego początku swojego istnienia, a mianowicie $\mathrm{z}$ trudnością pogodzenia ortodoksji i ortopraksji. Nie wystarczy, aby Kościół był wolny od źle pojętego augustynizmu bądź semipelaganizmu na poziomie doktryny. Chodzi o to, by nie był także de facto semipelagiański bądź jansenistyczny na poziomie praktyk. Jeśli, jak sądził Tischner, chrześcijaństwo jest jeszcze przed nami ${ }^{56}$, musimy ciągle uczyć się nie tylko tego, co myśleć o Bogu, ale jak przekładać to myślenie na praktykę (przede wszystkim w jej wymiarze duszpasterskim).

Kołakowski słusznie diagnozuje, że istotnym elementem sporu toczącego się w wieku XVII była teologia stworzenia. Pisał: „Spór dotyczył duchowych fundamentów chrześcijaństwa; można w nim upatrywać reaktualizację - w nowej sytuacji kulturalnej - nie kończącego się nigdy konfliktu, jaki kryje się u korzeni chrystianizmu, w samej wieloznaczności idei stworzenia" ${ }^{37}$. Jego zdaniem optymistyczne podejście do natury sytuuje nas po stronie molinistów, zaś podkreślanie przepaści między Bogiem a stworzeniem sprawia, że zajmujemy pozycję jansenistyczną. Konflikt ten zdaniem Kołakowskiego wyrasta z idei „nieskończonego władcy powołującego do istnienia rzeczy skończone"58.

Jak przypomina Tischner, błąd takiego myślenia bierze się stąd, iż stworzenie pojmuje się tu in abstracto. Tymczasem, aby pojąć je właściwe, należy spojrzeć na nie w kontekście dziejów zbawienia. Właśnie

\footnotetext{
56 Tischner pisał: „Mam takie przekonanie, iż chrześcijaństwo - Ewangelię - mamy nie tyle za sobą, ile przed sobą" (J. Tischner, Wiara $w$ godzinie przełomu, w: J. Tischner, Ksiądz na manowcach, dz. cyt., s. 13). W eseju tym, poświęconym współczesnej sytuacji polskiego chrześcijaństwa, Tischner przywołuje także poglądy Kołakowskiego, zawarte w jego książce Świadomość religijna i więź kościelna. Studia nad chrześcijaństwem bezwyznaniowym XVII wieku (Warszawa 1997).

57 L. Kołakowski, Bóg nam nic nie jest dłużny, dz. cyt., s. 88.

58 L. Kołakowski, Bóg nam nic nie jest dłużny, dz. cyt., s. 89.
} 
z tego powodu chrystologia nie jest zbędnym dodatkiem ani ucieczką z trudnej teoretycznie sytuacji, lecz istotą chrześcijańskiego myślenia o relacji między łaską i wolnością. Nie da się bowiem mówić o dramacie, którego częścią jest relacja łaski i wolności, bez odniesienia do wcielenia i życia w Duchu Świętym. Poprawne widzenie wolności możliwe jest, jak podkreśla Tischner, jedynie „w horyzoncie wcielenia" ${ }^{59}$. Dokładnie w tym samym horyzoncie należy patrzeć na problem łaski.

Już te dwa istotne postulaty dotyczące zagadnień teologicznych i ich teologicznych oraz duszpasterskich konsekwencji pokazują, ile można się nauczyć dzięki uważnemu przyglądaniu się sporowi Tischnera z Kołakowskim. Stanowiska w sporze o relację łaski i wolności niosą jednak różne konsekwencje nie tylko w obszarze myślenia religijnego, lecz także w obszarach teorii wychowania i polityki. Jak zaznaczyłem na początku, właśnie $z$ tego powodu nie można traktować tego zagadnienia jako kwestii czysto teologicznej, lecz należy do niej podchodzić jako do zagadnienia mającego swoją filozoficzną warstwę.

Można zasugerować, że pelagianizm i augustynizm niosą ze sobą znacząco różniące się obrazy, najlepiej wyrażające to, o co chodzi w każdym ze stanowisk. Pelagianizm przywołuje obraz dorosłego człowieka, który jest w stanie podjąć duchową walkę i odnieść w niej zwycięstwo. Zgodnie z tym obrazem Bóg jest wychowawcą człowieka i udziela mu niezbędnej pomocy w postaci dobrych rad i wsparcia. Augustynizm w wersji jansenistycznej przywołuje z kolei obraz małego, przestraszonego dziecka, które potrzebuje pomocy i tuli się w ramionach Boga. Semipelagianizm, mający stanowić rozwiązanie kompromisowe w stosunku do dwóch poprzednich, przynosiłby obraz młodego człowieka, który już potrafi walczyć i być wierny, ale potrzebuje większej dozy pomocy i wsparcia niż człowiek dorosły.

Opowiedzenie się za którymś z tych obrazów niesie konsekwencje na poziomie myślenia o wychowaniu i o polityce. Jeśli przyjąć za adekwatny do opisu omawianych rzeczywistości obraz dorosłego 
człowieka, to nie do przyjęcia jest wychowanie poprzez dyscyplinę. Nie do przyjęcia jest także, na gruncie myślenia o życiu politycznym, żaden rodzaj przymusu. Jeśli jednak nie jest adekwatny, może się okazać, że wychowanie bez dyscypliny i polityka opierająca się na zbyt wielkim zaufaniu do ludzkiej dojrzałości mogą przynieść efekt w postaci społeczeństwa barbarzyńców - ludzi, którym brakuje rozeznania co do podstawowych wartości i skoncentrowanych jedynie na własnych interesach.

Z kolei obraz małego bezradnego dziecka, gdyby uznać go za odpowiedni do opisu, prowadzi do postulatu daleko posuniętych ingerencji w proces wychowania i daleko posuniętych działań ze strony Kościoła czy państwa, zmierzających do zaprowadzenia porządku i wdrożenia wartości. Jeśli jednak obraz ten nie oddaje opisywanej rzeczywistości, może się okazać, że posługując się nim, doprowadzimy do stworzenia społeczeństwa składającego się z ludzi niepotrafiących samodzielnie myśleć i podejmować odpowiedzialności. Na poziomie życia politycznego konsekwencją będzie wówczas zgoda na kościelny bądź państwowy terror.

I wreszcie warto rozważyć obraz młodego człowieka, który potrafi walczyć i być wierny, lecz potrzebuje jeszcze pomocy. Jeśli to ten obraz okaże się słuszny i adekwatny, to odwołanie się do niego będzie prowadzić do wychowania koncentrującego się na potrzebach, o których informują wychowawców wychowankowie, a jego skutkiem na poziomie polityki będzie umiarkowany interwencjonizm. Jeśli jednak wspomniany obraz będzie nieadekwatny, to może się okazać, że przesadna ufność pokładana w wychowankach doprowadzi do głębokiego zagubienia, ponieważ będzie skutkować rodzajem wychowania rozumianego jako eksperyment. Na poziomie życia politycznego natomiast może być trudno wyznaczyć granice dopuszczalnych interwencji i znaleźć dla nich uzasadnienie.

Idąc śladem myśli Tischnera, można twierdzić, że przyszedł czas, by na nowo ożywić inny jeszcze obraz, obecny stale w myśli biblijnej, lecz nie dość jeszcze zrozumiany i przyswojony. Jest to obraz relacji oblubieńczej. Taka relacja pozwala wyzwolić się ze strachu, jaki wiąże się 
z ujmowaniem problemu w kategoriach augustyńskich, pozwala również odsunąć obraz człowieka działającego „na własną rękę”, niejako „poza” Bogiem czy „wbrew” Bogu. Także ten obraz ma swoje wychowawcze i polityczne konsekwencje.

Patrzenie na relację między człowiekiem a Bogiem jako na relację oblubieńczą może przyczynić się do radykalnej zmiany naszego myślenia o Bogu i o człowieku. Chodzi o to, by dojrzeć do tej starej koncepcji, by ją zrozumieć i zacząć wprowadzać w życie. Jeśli uda się nam ją przyswoić, jeśli do niej dorośniemy, inne będzie wychowanie, inna też będzie polityka. Jeśli chodzi o to pierwsze, kluczem do niego może stać się odsłanianie wartości, których realizacja ma być nie tyle obowiązkiem wychowanka, ile najgłębszym jego pragnieniem. Odsłanianie wartości zaś nie wiąże się z przymusem, lecz z wyzwalaniem wolności. Jak przypomina Tischner, im wyższa wartość, tym większa wolność ${ }^{60}$. W odniesieniu do polityki kluczem zaś staje się pojęcie „uczestnictwa”" które nie tylko wyklucza przymus, lecz także czyni go zbędnym. Jeśli jednostka i wspólnota (czy będzie nią Kościół, czy też państwo) nie działają przeciw sobie, lecz ze względu na te same wartości, wówczas nie zachodzi konieczność interwencji.

\section{Zakończenie}

Spór Tischnera z Kołakowskim, choć wydaje się dotyczyć jedynie niezwykle zaawansowanych teoretycznie wątków teologicznych, ma znaczenie istotnie wykraczające poza teologię. Ważną dla rozstrzygnięcia tego sporu kwestią okazuje się poprawne rozumienie jego dziejów. Tylko wówczas bowiem, gdy poprawnie pojmuje się sens wchodzących w grę rozwiązań, można przeprowadzić ich zasadną krytykę, jak również sformułować własne stanowisko.

60 Zob. J. Tischner, Wolność w blasku prawdy, w: J. Tischner, W krainie schorowanej wyobraźni, Kraków 2013, s. 169. Bądź w innym sformułowaniu: „Im wyższa wartość, tym większa swoboda jej uznania” (J. Tischner, Myślenie według wartości, „Znak” (1978) nr 7-8, s. 960-961).

${ }^{61}$ Powiązanie łaski i uczestnictwa polega na tym że, jak przypomina Tischner, „łaska wprowadza na w uczestnictwo" (J. Tischner, J. Żakowski, Tischner czyta Katechizm, Kraków 2000, s. 128). 
Najważniejsze w tym sporze jest jednak to, że ma on swoje przedłużenie w naszych czasach. Okazuje się, że dyskusje o zawiłościach XVII-wiecznego sporu między jansenistami i molinistami, jak również precyzyjne odróżnianie „pelagianizmu” od „semipelagizmu”, choć stanowią, jak zauważa Tischner, świetne ćwiczenie umysłowe ${ }^{62}$, są czymś znacznie więcej. W tym sporze chodzi o nas, którzy czujemy się szarpani przez dwie siły. Oglądamy w nim nasze własne rozdarcie ${ }^{63}$.

Warto więc przyglądać się dysputom Augustyna z Pelagiuszem, Pascala i jego jansenistycznych towarzyszy z teologami jezuickimi. Jeszcze bardziej warto przyjrzeć się uważnie sporowi Tischnera z Kołakowskim. Każdy z nas, chcąc, nie chcąc, musi wziąć udział w tych sporach i rozstrzygnąć je na własną rękę. Od ich rozstrzygnięcia zależy to, co myślimy o właściwych sposobach wychowywania następnych pokoleń i o polityce. Już to pokazuje, jak ważne są to spory. Jeszcze istotniejsze stają się one wówczas, gdy zdamy sobie sprawę, że od ich rozstrzygnięcia zależy nie tylko nasz los doczesny, lecz także wieczny.

\section{Bibliografia}

Augustyn św., Łaska a wolna wola, w: św. Augustyn, Łaska, wiara, przeznaczenie, tłum.

E. Eborowicz, Poznań- Warszawa-Lublin 1970, s. 51-148.

Augustyn św., Nagana i łaska, w: św. Augustyn, Łaska, wiara, przeznaczenie, tłum.

E. Eborowicz, Poznań- Warszawa-Lublin 1970, s. 149-205.

Bouyer L., Duch Święty Pocieszyciel, tłum. A. Liduchowska, Kraków 1998.

Grossi V., Ladaria L., Lécrivain P., Sesboüé B., Historia dogmatów, t. 2: Człowiek i jego zbawienie, tłum. P. Rak, Kraków 2001.

Kijewska A., Augustyńskie dziedzictwo, w: Przewodnik po filozofii średniowiecznej. Od św. Augustyna do Joachima z Fiore, red. A. Kijewska, Kraków 2012, s. 17-41.

Kołakowski L., Banał Pascala, w: L. Kołakowski, Chrześcijaństwo, wstęp, wybór i opracowanie H. Czyżewski, Kraków, s. 236-244.

62 Zob. J. Tischner, Podglądanie Pana Boga, dz. cyt., s. 252.

${ }^{63}$ Zob. J. Tischner, Szukając mistrzów naszej wiary, dz. cyt., s. 247. 
Kołakowski, Bóg nam nic nie jest dłużny. Krótka uwaga o religii Pascala i o duchu jansenizmu, tłum. I. Kania, Kraków 1994.

Kołakowski L., Erazm i jego Bóg, w: L. Kołakowski, Chrześsijaństwo, wstęp, wybór i opracowanie H. Czyżewski, Kraków 2019, s. 29-39.

Kołakowski L., Świadomość religijna i więź kościelna. Studia nad chrześcijaństwem bezwyznaniowym XVII wieku, Warszawa 1997.

Kołakowski, Światopogląd XVII stulecia, w: L. Kołakowski, Chrześcijaństwo, wstęp, wybór i opracowanie H. Czyżewski, Kraków 2019, s. 142-166.

Kołakowski L., Zaproszenie od Pana Boga na biesiadę. Dialog XVII-wieczny, w: L. Kołakowski, Czy Pan Bóg jest szcześliwy i inne pytania, wybór i układ Z. Mentzel, Kraków 2009, s. 20-24.

Müller G., Dogmatyka katolicka, tłum. W. Szymona, Kraków 2015.

Oko D., Łaska i wolność. Łaska w Biblii, nauczaniu Kościoła i teologii współczesnej, Kraków 1997.

Tischner J., Myślenie według wartości, „Znak” (1978) nr 7-8, s. 957-970.

Tischner J., Podglądanie Pana Boga, w: J. Tischner, Ksiądz na manowcach, Kraków 1999, s. 251-276.

Tischner J., Szukając mistrzów naszej wiary, w: J. Tischner, Ksiądz na manowcach, Kraków 1999, s. 236-250.

Tischner J., Spór o istnienie człowieka, Kraków 2011.

Tischner J., Wiara w godzinie przełomu, w: J. Tischner, Ksiądz na manowcach, Kraków 1999, s. 11-29.

Tischner J., Wolność w blasku prawdy, w: J. Tischner, W krainie schorowanej wyobraźni, Kraków 2013, s. 159-173.

Tischner J., Zarys filozofii człowieka dla duszpasterzy i artystów, w: J. Tischner, Myślenie w żywiole piękna, Kraków 2013, s. 139-336.

Tischner J., Żakowski J., Tischner czyta Katechizm, Kraków 2000.

\section{Abstrakt}

\section{Tischnera z Kołakowskim spór o łaskę i wolność}

Niniejszy tekst traktuje o jednej z odsłon zapoczątkowanego przez Pelagiusza i św. Augustyna sporu o łaskę i wolność. Bohaterami tej odsłony sporu są Leszek 
Kołakowski i Józef Tischner. Kołakowski, rekonstruując XVII-wieczne dyskusje między jansenistami i molinistami, stawiał pytanie o znaczenie tego sporu dla współczesności. Tischner, krytykując poglądy Kołakowskiego, proponował własne, idące śladem myśli św. Augustyna, rozwiązanie problemu łaski i wolności. W niniejszym tekście umieszczam spór Tischnera z Kołakowskim na tle starszych odsłon sporu i omawiam poglądy obu myślicieli. Podejmuję także próbę rozstrzygnięcia tego sporu oraz wskazuję jego znaczenie dla filozofii wychowania i filozofii polityki.

\section{Słowa kluczowe}

Józef Tischner, Leszek Kołakowski, łaska, wolność, augustynizm, pelagianizm, semipelagianizm 